\title{
Ekphrasis em música: os Quadrados Mágicos de Paul Klee na Sonata para violão solo de Leo Brouwer
}

\author{
Ricardo Marçal de Souza e Silva (UFMG, Belo Horizonte) \\ ricardomarcal@hotmail.com
}

\begin{abstract}
Resumo. Para Siglind Bruhn, o conceito de ekphrasis, usado nas artes plásticas e na literatura, pode ser aplicado também para certas obras musicais. Partindo dessa concepção, desenvolvida pela autora na obra Musical Ekphrasis: composeres responding to poetry and painting este artigo investiga a apropriação que o compositor cubano Leo Brouwer (1939 - ) faz, no primeiro movimento de sua Sonata para violão solo, de certos procedimentos composicionais utilizados pelo pintor suiço Paul Klee (1879-1940) em sua série de pinturas intitulada Quadrados Mágicos, caracterizando, assim, uma ekphrasis.
\end{abstract}

Palavras-chave: ekphrasis, Brouwer, Sonata, Klee, Quadrados Mágicos.

\section{Ekphrasis in music: the Magic Squares by Paul Klee in the Sonata for solo guitar by Leo Brouwer}

Abstract. For Siglind Bruhn, the concept of ekphrasis, used on visual arts and literature, can be applied to certain pieces of music. Starting from this concept, developed by Bruhn on the work Musical Ekphrasis: composeres responding to poetry and painting, the present article investigates the appropriation that the Cuban composer Leo Brouwer (1939 - ) makes, on the first movement of his Sonata for solo guitar, of certain compositional procedures used by the Swiss painter Paul Klee (1879-1940) in his series of pictures entitled Magic Squares, characterizing, thus, an ekphrasis.

Keywords: ekphrasis, Brouwer, Sonata, Klee, Magic Squares.

\section{1- Introdução}

Filho de músicos, Paul Klee (1879 - 1940) durante muito tempo oscilou entre a carreira de musicista ${ }^{1}$ e pintor. Em 1912 ele participou de um grupo de artistas expressionistas - que se tornaria famoso sob o nome de "Der Blaue Reiter" -, que buscavam a utilização de valores musicais e espirituais no desenvolvimento da arte abstrata (BRUHN, 2000, p.595); e, de fato, acabou criando uma obra pictórica onde, entre outras coisas, materiais originalmente musicais são aproveitados das mais diferentes formas. ${ }^{2}$ Poderiamos citar alguns exemplos, como Fugue in Red, de 1921, e Colour Table (in Major Grey), de 1930 - em cujos títulos já se verifica certa sinestesia ${ }^{3}$-, ou Polyphony, de 1932 e Harmony of Rectangles in Red, Yellow, Blue, White and Black, de 1923 - onde ele realiza uma apropriação e adaptação de conceitos da linguagem musical.

Mas, segundo DI SAN LAZZARO (1965, p.172), é em sua série de Quadrados Mágicos que Klee se revela como um dos maiores pintores de sua época:

"A cor em Klee, que em várias de suas obras é meramente um fundo opaco sobre o qual seu sujeito é graficamente representado, e em outras tem a límpida transparência do vidro ou uma brilhante propriedade, nos 'quadrados mágicos' é um nobre meio de exp ressão. (...) 0 misticismo e a sensualidade de Klee se fundem perfeitamente nessa sublime harmonia abstrata, que tem exercido tão grande influencia na pintura moderna."

0 compositor cubano Leo Brouwer (1939 - ) aproveitou a idéia dos quadrados de Klee em algumas de suas obras como a Parábola (1973) e, notadamente, no primeiro movimento de sua Sonata (1990), conforme DEVINE (2006). ${ }^{5}$

A Sonata para violão solo foi por ele escrita em setembro de 1990, a pedido do violonista britânico Julian Bream, para o qual o compositor já havia escrito o Concerto Elegíaco (1986) para violão e orquestra. Embora Brouwer seja o autor de uma das mais importantes e vastas obras para violão do século $X X$, essa é, até o momento, a única peça que ele escreveu para o instrumento com esse título. Possui três movimentos: Fandangos y Boleros, Sarabanda de Scriabin e La Toccata de Pasquini.

Tanto Brouwer quanto Klee realizam, cada um a sua maneira, o que BRUHN (2000) chama de ekphrasis, que a própria autora, em meio a outras definições, conceitua 
como "a representação em um meio de expressão de um texto composto em outro meio" (BRUHN, 2000, p.8). Segundo ela, a busca por um termo e por uma metodologia que pudesse investigar a possibilidade da música "falar sobre" coisas extra-musicais sempre a intrigou, o que a levou a perseguir essa questão durante décadas (idem, p.xiii). Este conceito, tradicionalmente usado nas artes plásticas e, sobretudo, na literatura, tem seu uso e aplicação à arte musical defendido pela autora, que considera três elementos da ekphrasis na gênese da obra (idem, p.8): uma cena, estória - ou qualquer coisa a ser representada -, fictícia ou real; sua representação num texto visual ou verbal; a transposição, suplementação, associação ou interpretação dessa representação para a linguagem musical (idem, p.57, 64, 67 e 72).

Partindo desse princípio, a autora realiza análises de diversas obras em diferentes meios, considerando a pintura e a literatura "imitando" a música (idem, p.81106); em seguida exemplifica casos em que a transição é feita da palavra e da imagem para o som, analisando exemplos em obras de compositores como Debussy, Hindemith, Schoenberg, Elliott Carter e Peter Maxwell Davies. Nesse processo, ela inclusive propõe parâmetros de análise, considerando, entre outras coisas, ritmo, alturas, intervalos, timbres, significados estruturais e texturais, alusões, simbolismos, entre outros (idem, p.561-574).

Este artigo pretende investigar como Leo Brouwer utilizou os Quadrados Mágicos de Paul Klee na composição do primeiro movimento (Fandangos y Boleros) de sua Sonata para violão solo, considerando a idéia de ekphrasis em música sugerida por Bruhn. Para isso, será utilizada a metodologia proposta pela autora: uma análise da peça musical em questão seguida da investigação dos elementos de ekphrasis.

\section{2- Análise}

0 primeiro movimento (Fandangos y Boleros) da Sonata é subdividido pelo próprio compositor nas seguintes seções: Preámbulo - que utiliza uma linguagem mais pontilhista, dando a impressão de um caráter mais improvisatório, expondo e realizando variações sobre algumas das células geratrizes da peça; Danza - em que as mesmas células começam a ganhar maior organização através do estabelecimento de uma métrica; Alla Danza - em que esse aspecto métrico se aprofunda, enquanto começam a se esboçar polarizações harmônicas mais claras; Alla Danza novamente, e, uma Coda onde toda essa organização é explicitada e traduzida através de citações de Antonio Soler (1729-1783) e Ludwig van Beethoven (1770-1827). Em termos formais, a sonata não se evidencia aqui por uma construção convencional, mas, sobretudo, pelo jogo dialético entre materiais que, colocados em oposição, vão se "reconciliando" - inclusive harmonicamente, até o final.

0 primeiro compasso, que dá início ao Preámbulo, estabelece esse arquétipo ${ }^{6}$ da construção da peça: ele enuncia os dois materiais que serão desenvolvidos dando discursividade e articulação à Sonata: um Sol \#, tocado como harmônico na

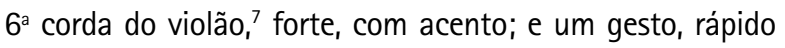
(figuração rítmica em fusas), meno sonoro, terminado em um Solq que se estende com uma fermata, sugerindo uma "nuvem" em torno dessa última nota, provocada pela ressonância das demais (Fig.1).

A transformação desses dois materiais, que já se inicia a partir do segundo compasso, gerando um crescente acúmulo de tensão, dará origem à grande oposição que caracteriza a macro-forma: a que se dá entre os Fandangos e os Boleros anunciados no título do movimento (Fig.2).

É importante frisar que algumas dessas variações serão exploradas mais adiante enquanto motivos - a exemplo das duas colcheias que formam um intervalo de sétima descendente no c.5 (Fig.3).

0 c.7 apresenta uma novidade no desenvolvimento do primeiro dos dois materiais: sua transformação em um motivo aparentemente inspirado em obras do compositor russo Alexander Scriabin (1872-1915), que aparece com a indicação de ritmico e mosso (Fig.4, delimitado por um retângulo), utilizando de forma insistente o intervalo de terça menor (Fig.4) - já a presentado no primeiro compasso, e que será amplamente trabalhado na seqüência; no entanto, esse tema reaparecerá com uma formatação mais completa e com um uso mais freqüente no segundo ${ }^{8}$ e terceiro movimentos da Sonata.

Segundo Devine, esse tema foi extraído da Sonata $n^{\circ} 9$ para piano, 0p.68 de Scriabin. Entretanto, procedendo a uma atenta procura no texto musical da mesma, não conseguimos verificar sua presença. Mas motivos semelhantes - pelo uso da repetição de notas seguida de saltos de segunda menor ascendente ou descendente e a

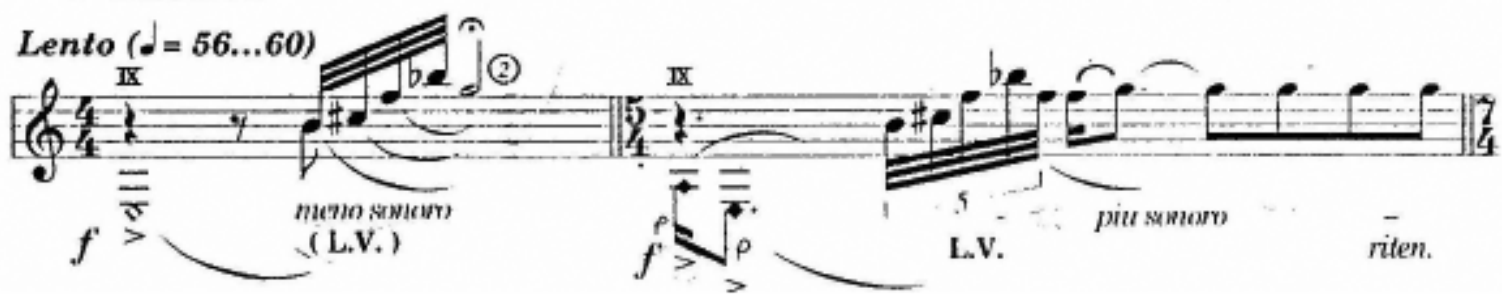

Fig.1: Fandangos y Boleros, "Preâmbulo", c.1-2 

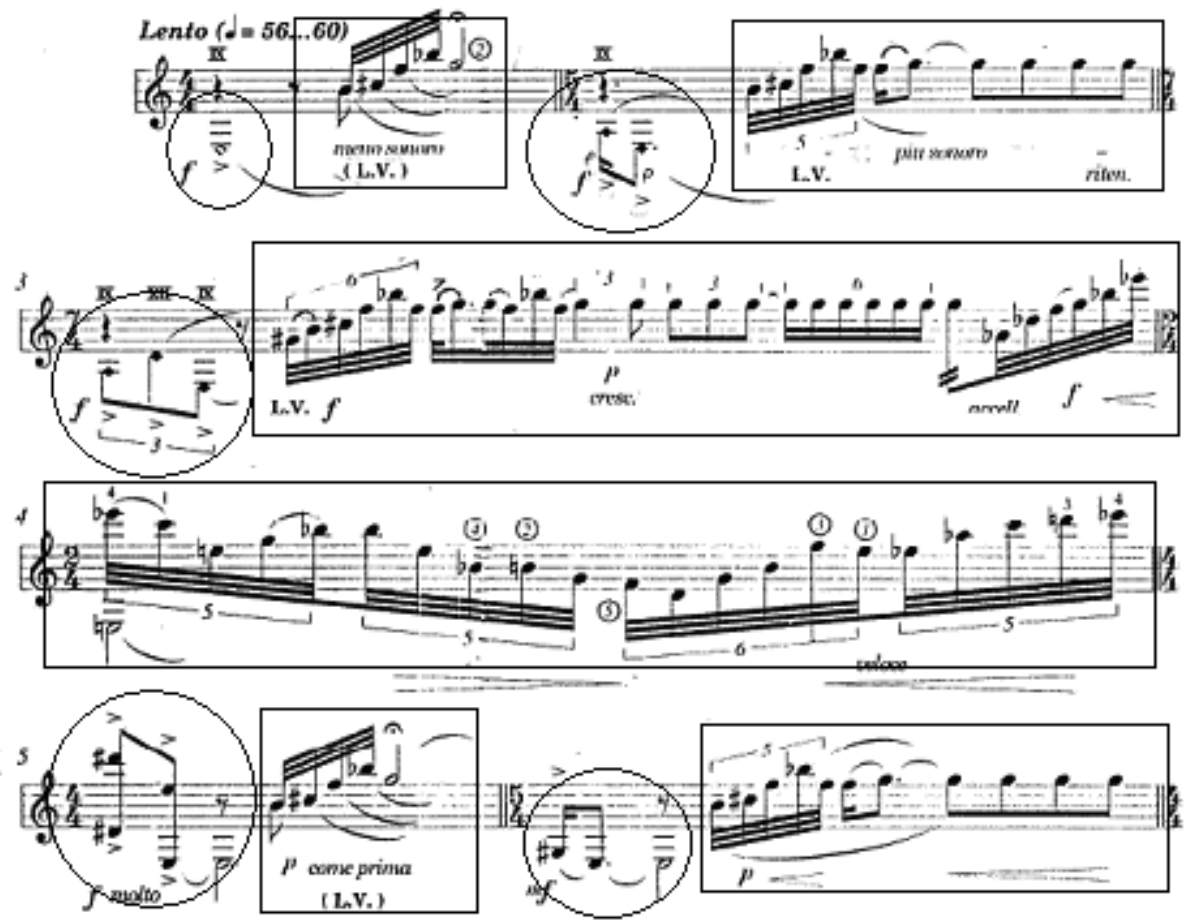

Fig.2: Fandangos y Boleros, "Preámbulo": Variações do motivo do c.1 nos c.2-6

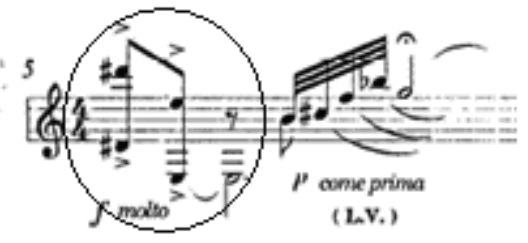

Fig.3: Fandangos y Boleros, "Preámbulo", c.5

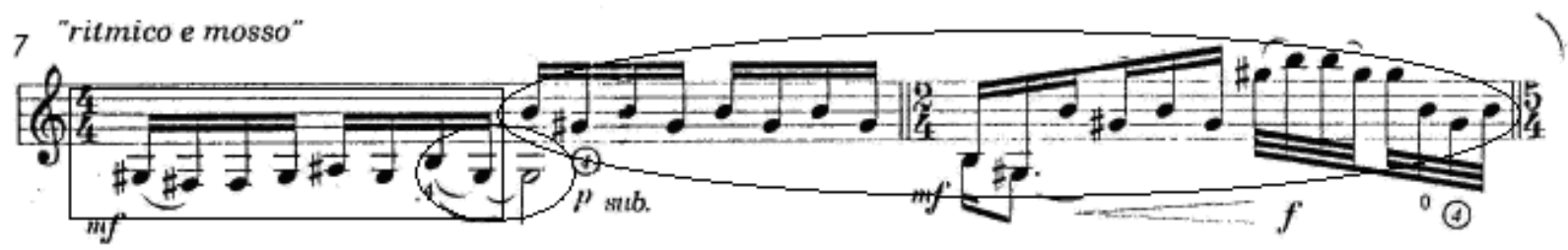

Fig.4: Fandangos y Boleros, "Preâmbulo", c.7-8

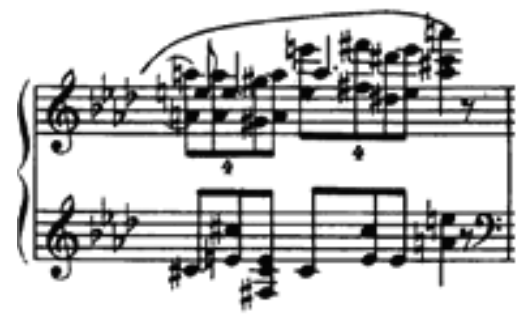

Fig.5: Alexander Scriabin, Sonata $n^{\circ} 1$ para piano, Op.6: c.38 
recorrência de terças menores - podem ser encontrados, por exemplo, no primeiro movimento de sua Sonata $n^{\circ}$ 1 para piano, Op.6 (Fig.5), ou no terceiro movimento de sua Sonata $n^{\circ} 3$ para piano, 0p.23 (Fig.6):

A importância da citação a Scriabin será mais bem aquilatada no estudo sobre a ekphrasis dessa obra.

Logo nos c.10-12 se delineia ainda mais o motivo de terça menor extraído do tema de Scriabin (circulado na Fig.4 acima), surgindo como um eco (dentro dos retângulos da Fig.7), bem como as duas colcheias em sétima descendente do c.5 (dentro dos círculos da Fig.7):

A sucessão de variações dos motivos iniciais continua ininterrupta - até o advento da Danza.

Em relação ao delineamento melódico e à textura, a Danza demonstra clara derivação do primeiro compasso (Fig.8 e Fig.9):

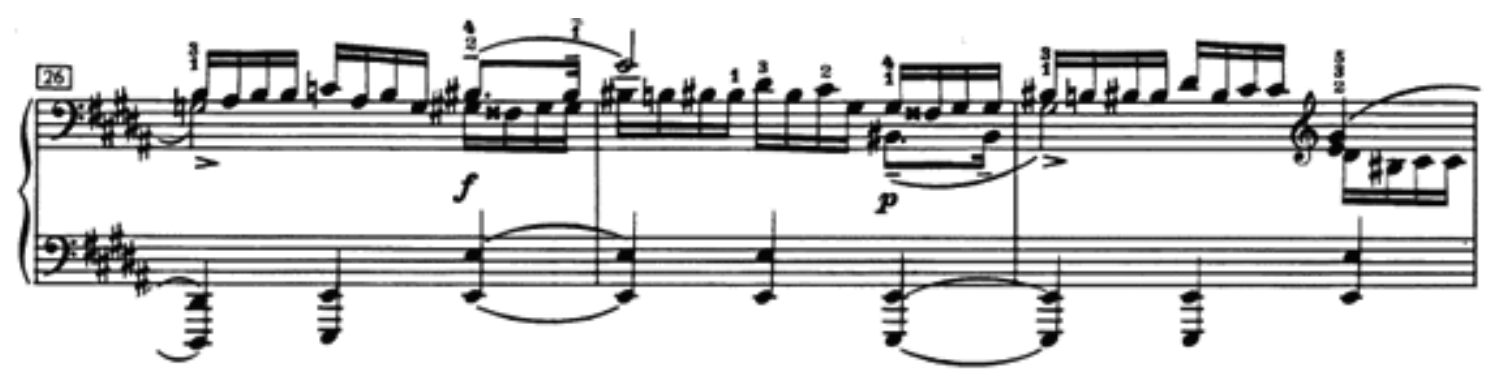

Fig.6: Alexander Scriabin, Sonata $n^{\circ} 3$ para piano, Op.23, $3^{\circ}$ movimento: c.26-28

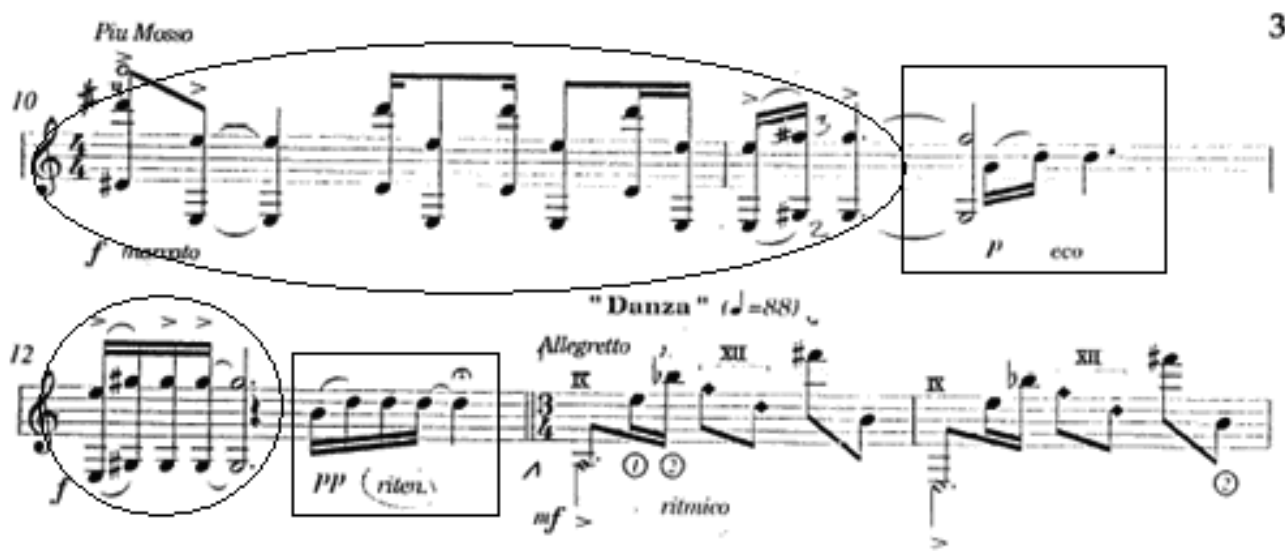

Fig.7: Fandangos y Boleros, "Preâmbulo", c.10-14

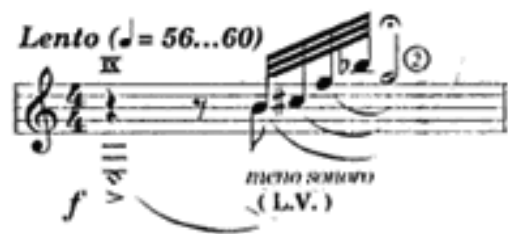

Fig.8: Fandangos y Boleros, "Preâmbulo", c.1

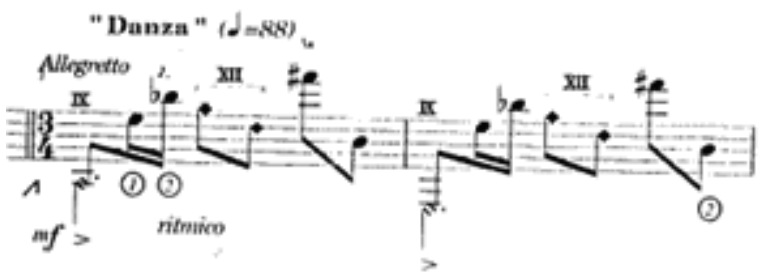

Fig.9: Fandangos y Boleros, "Danza", c. 13-14 
A utilização de uma nota pedal ${ }^{9}$ na região mais grave na cabeça do compasso, bem como o já destacado intervalo de terça menor provocado pelo $\mathrm{Si}$-Sol na região aguda e o conseqüente "colorido" são alguns dos aspectos que demonstram a afinidade das duas passagens.

0 que ocorre na Danza, e isso a caracteriza como tal, é uma maior simetria rítmica, derivada, ao mesmo tempo, do padrão do bolero ${ }^{10}$ (Fig.10):

e da retrogradação rítmica da segunda citação importante realizada no primeiro movimento, e que virá somente na Coda: a do tema da Sinfonia $n^{\circ} 6$ de Beethoven (Fig.11 e Fig.12).
Além disso, o c.17 apresenta uma nova derivação daquele primeiro compasso (Fig.13), numa figuração que exigirá do intérprete um balanceamento e uma hierarquização das texturas da Danza (além de um pouco de virtuosismo!): um "gesto" rápido e cheio daquele colorido característico, e que será desenvolvido nos próximos seis compassos, após o qual o modo inicial da Danza retorna com as indicações Alla Danza e come prima.

0 c.29 apresenta um novo padrão rítmico (Fig.14)e inicia uma nova seção onde os dois materiais do início da peça serão colocados novamente em oposição, agora de forma mais complementar. 0 primeiro deles, que deu origem a

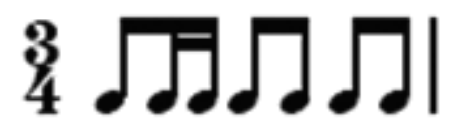

Fig.10: padrão rítmico do bolero

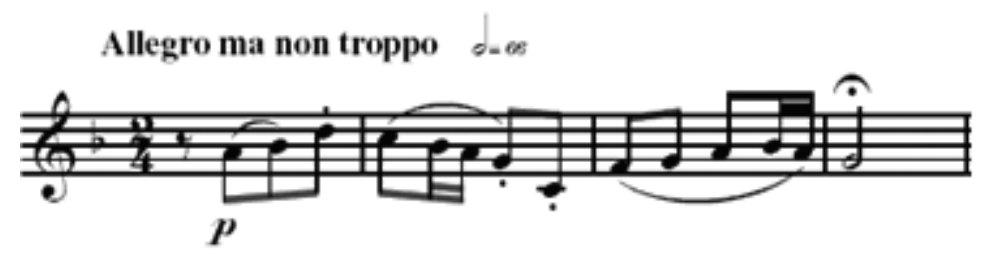

Fig.11: Tema da Sinfonia n. 6 em Fá Maior ("Pastorale"), 0p.68, de L. V. Beethoven

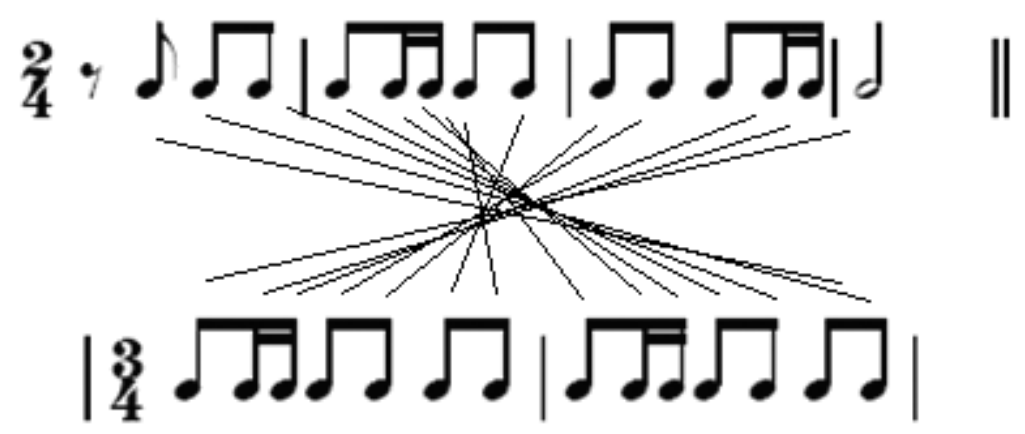

Fig.12: redução rítmica do tema da Sinfonia $n^{\circ} 6$ de Beethoven comparada com a da Danza, respectivamente.

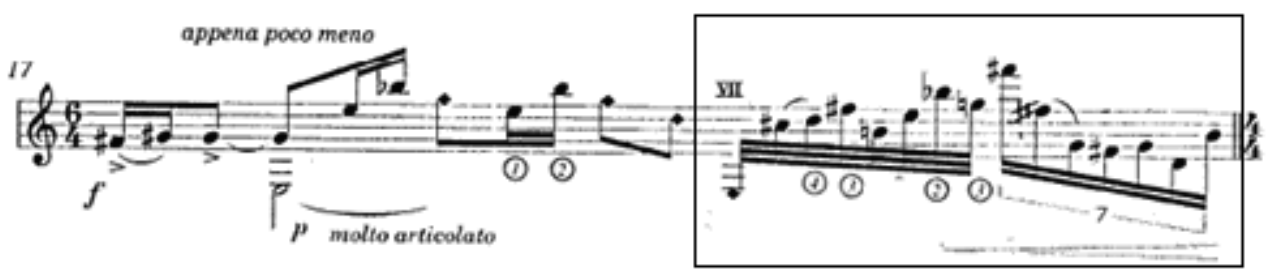

Fig.13: Fandangos y Boleros, "Danza", c.17 
uma série de ritmos e intervalos, é transformado agora numa outra dança, agora inspirada pelos fandangos ${ }^{11}$ de Antonio Soler ${ }^{12}$ - caracterizado segundo MARVIN (2001, p.633), por dissonâncias, síncopes e vistosas variações. Esta nova dança é apresentada e desenvolvida utilizando um percurso harmônico que simplesmente passa por certas regiões tonais, sem a intenção aparente de utilizar as funções dessas tonalidades para impulsionar a forma, mas simplesmente tratá-las, mais uma vez, como "colorido"; e acrescenta novamente a terça menor já exposta nos c.7, 11 e 12, que agora passará por um desenvolvimento.

Ora, o c.44 (Fig.15) realiza esse impulso formal que, ao invés do motivo de dança, recobra aquele gesto que caracterizamos como o segundo material da peça, e que surge aqui como uma inesperada interjeição.

Os compassos a seguir desenvolvem esse fandango entrecortado de violentas reminiscências do gesto inicial, onde o motivo de terça menor é explorado em diversas regiões ("coloridos"), bem como aquele motivo rítmico em colcheias, do c.5. Assim, destacando cada um desses motivos temos, na Fig.16: a) acima, circulado, o motivo de terça menor; b) no centro da figura, dentro de um retângulo, as rápidas interjeições; c) abaixo, também circulado, o gesto rítmico, inicialmente apresentado com figuração em colcheias e com um intervalo de sétima, sendo posteriormente transformado.

0 fato é que todos eles já se encontravam em gérmen nos materiais do primeiro compasso, e aqui, já devidamente potencializados, percorrem um desenvolvimento (Fig.17) que atingirá um climax, realizando uma clara articulação formal na peça.

A seção seguinte (Fig.18), também nomeada Alla Danza, dá mais um passo na organização dos materiais em termos de harmonia, ao se polarizar em torno de Dó Maior e de sua Mediante Ascendente, Mi Maior - já utilizada na Danza; desta é retomado também o ritmo. Mais uma vez, a métrica da seção gira em torno do retrógrado do ritmo do tema da Sinfonia $n^{\circ} 6$ - ou do padrão rítmico do bolero (ver Fig.10, 11 e 12 acima).

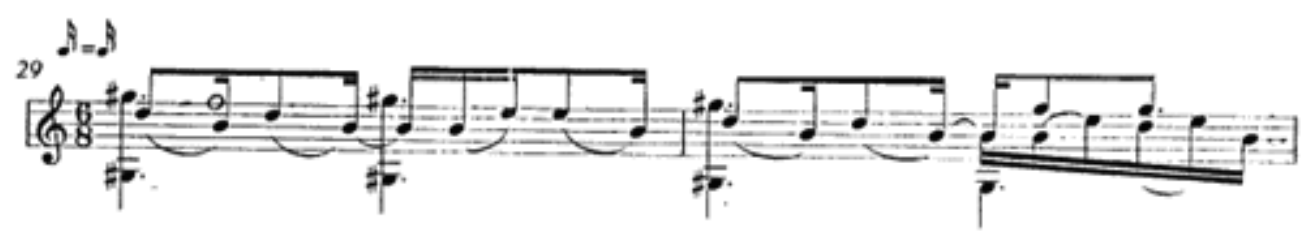

rig. 14: randangos y Boleros, "Alla Uanza”, c.2y-3U

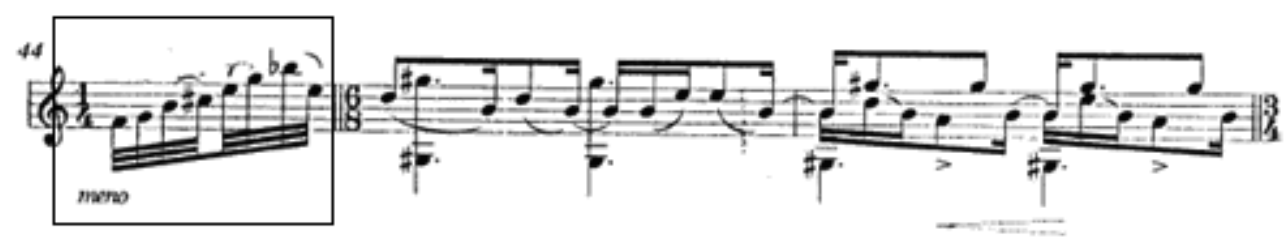

Fig.15: Fandangos y Boleros, "Alla Danza", c.44-46

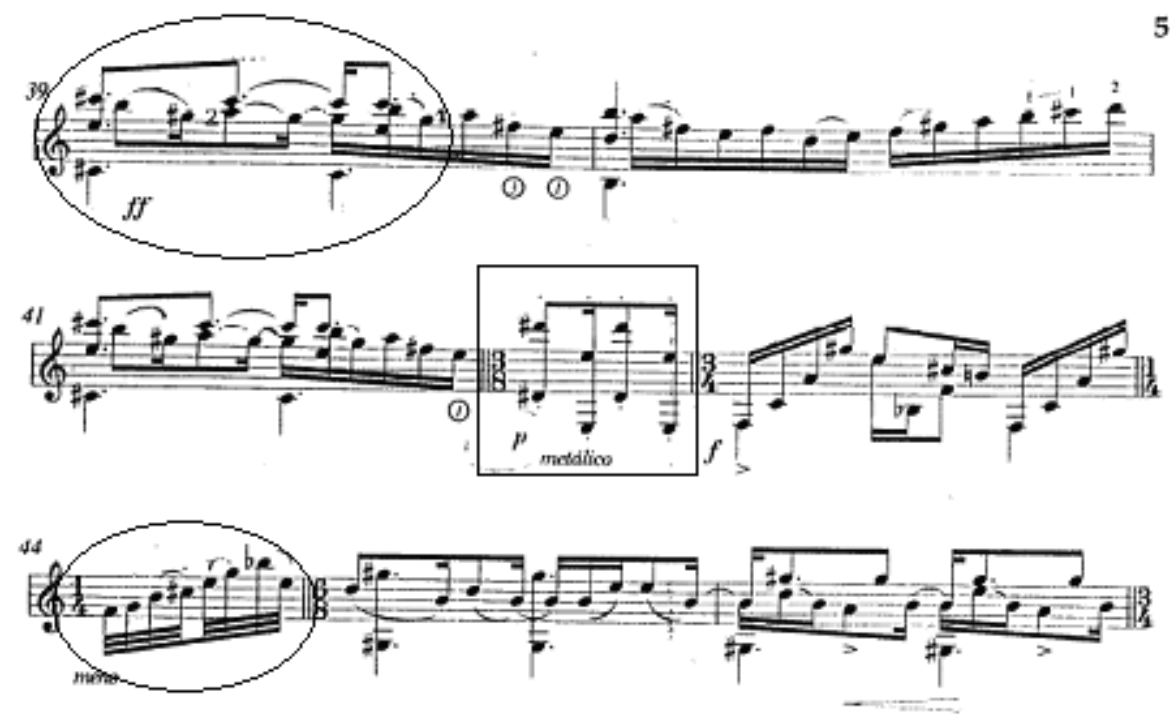

Fig.16: Fandangos y Boleros, "Alla Danza", c.39-46 
A repetição ternária desse padrã $0^{13}$, apenas expandida - de forma minimalista - em cada grupo de tônica/mediante, gera um efeito hipnótico, através do alargamento temporal e da expectativa gerada nos compassos seguintes. Poderíamos dar um exemplo dessa progressão analisando apenas as transformações do arpejo da região de Dó Maior (Fig.19):
A partir da quarta repetição desse padrão tônica/mediante, no c.87 (Fig.20), surge novamente a figura do gesto rápido/ interjeição, com efeito de coloratura, motivo que também será expandido, notadamente nas repetições que se iniciam nos c.93 e - uma aparente alusão ao processo iniciado no c.17 (Fig.21):
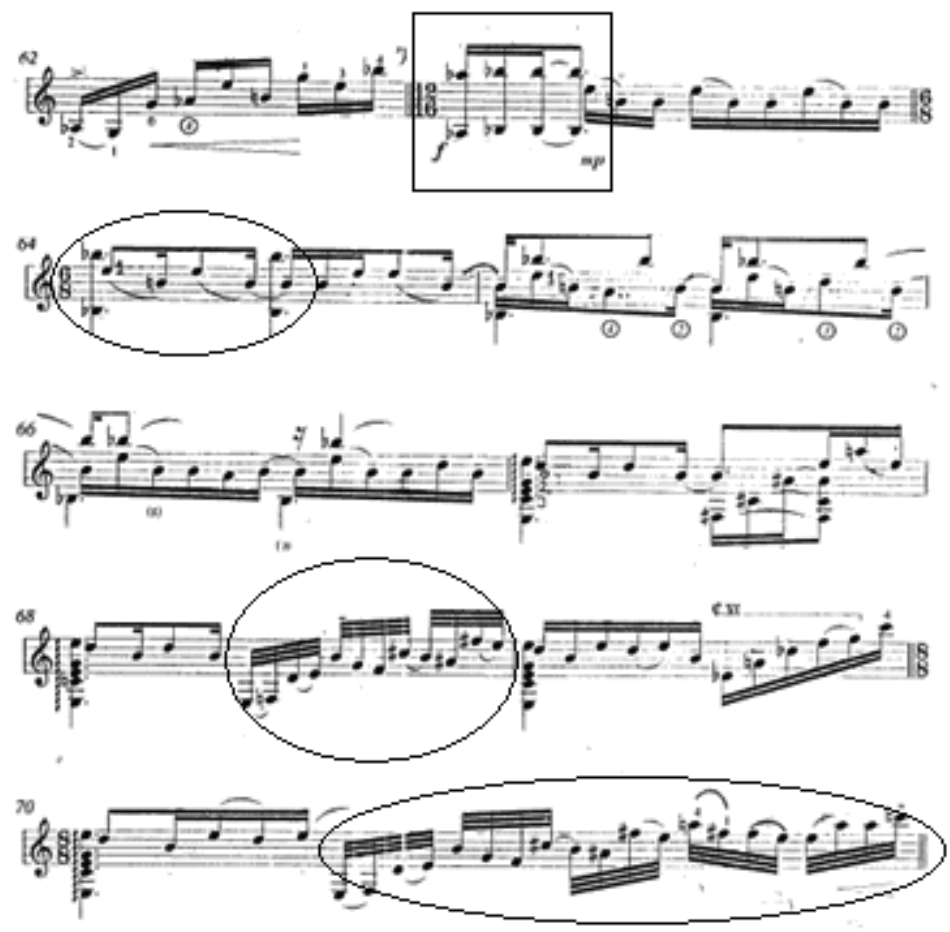

Fig.17: Fandangos y Boleros, "Alla Danza", c.62 -70: continuação do desenvolvimento dos motivos destacados anteriormente e articulação formal no c.70

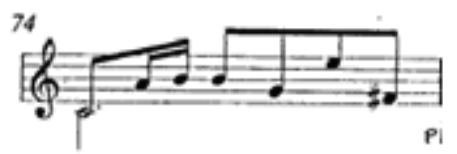

Fig.18: Fandangos y Boleros, "Alla Danza", c.74
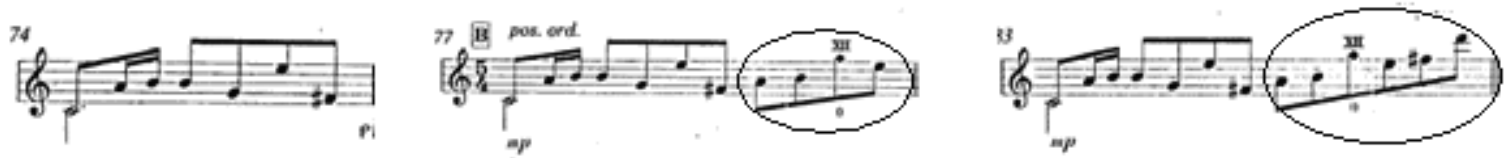

Fig.19: Fandangos y Boleros, "Alla Danza", c. 74, 78 e 83, respectivamente

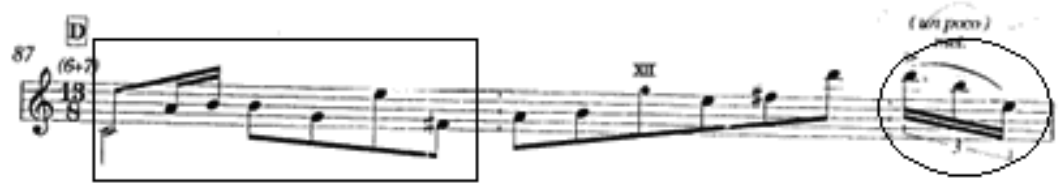

Fig.20: Fandangos y Boleros, "Alla Danza", c.87 
E o gesto rítmico em colcheias com um intervalo de sétima (apresentado no c.5) também possui sua contrapartida nesse novo desenvolvimento (Fig.22):

Essa série de repetições se encerra com os harmônicos Sol-Si tocados repetidamente na $3^{\mathrm{a}}$ e $2^{\mathrm{a}}$ cordas, respectivamente ${ }^{14}$, desaparecendo lentamente, decrescendo, ritardando e deixando um silêncio "prenhe" de expectativas, que é espetacularmente ocupado pela citação literal do tema da Sinfonia $n^{\circ} 6$ de Beethoven (Fig.23 e Fig.24), devidamente harmonizado no Dó Maior decorrente da seção anterior.

A "visita al Padre Soler" é em seguida justificada pela ocorrência de um fragmento do ostinato de fandango da Alla Danza, que passa a se alternar com pedaços do tema de Beethoven, por três vezes ${ }^{15}$; para, a seguir, reapresentar o motivo-arquétipo inicial (Fig.25):

Os compassos finais (Fig.26) aparentemente exibem uma sinopse do trabalho de desenvolvimento desse arquétipo: sua variação, transformação e organização (rítmica e harmônica) através da Danza e solução final e inequívoca em Dó Maior:

É interessante notar que o segundo movimento (Sarabanda de Scriabin), é escrito na tonalidade da Sinfonia $n^{\circ} 6$ de Beethoven, ou seja, Fá Maior - preparado, ainda nesse primeiro movimento, com o Dó final.

Tanto com relação às seções quanto à apresentação das células (arquétipos) geratrizes, podemos propor o seguinte diagrama do aspecto formal da peça (as setas indicam as derivações), considerando o que foi exposto logo no início e ao longo dessa análise (Fig.27):

Pode-se observar que a Danza que se segue ao Preámbulo Ihe é derivada, a mesma articulação ocorrendo entre a Coda e a Alla Danza; a Alla Danza central comporta-se, portanto, como uma autêntica intercessão.

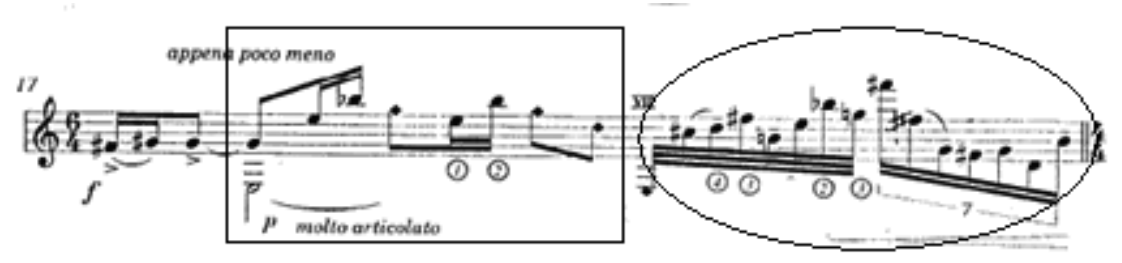

Fig.21: Fandangos y Boleros, "Alla Danza", c.17

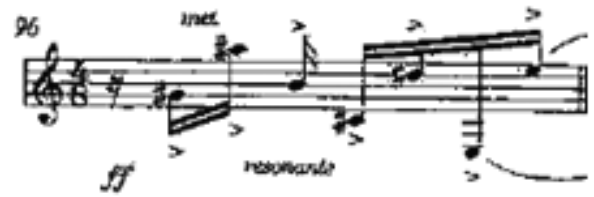

Fig.22: Fandangos y Boleros, "Alla Danza", c.96

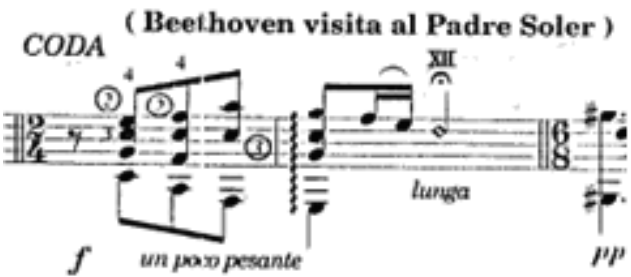

Fig.23: Fandangos y Boleros, "Coda", c.113: "Beethoven visita al Padre Soler"

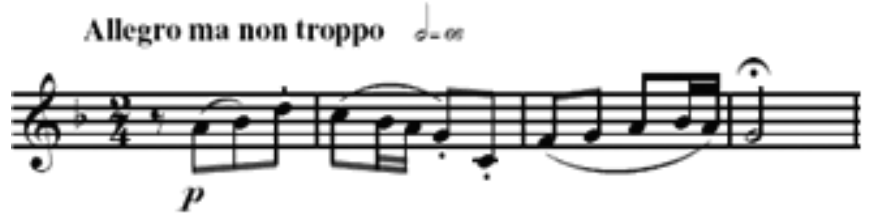

Fig.24: Tema da Sinfonia n 6 em Fá Maior ("Pastorale"), 0p.68, de L. V. Beethoven 


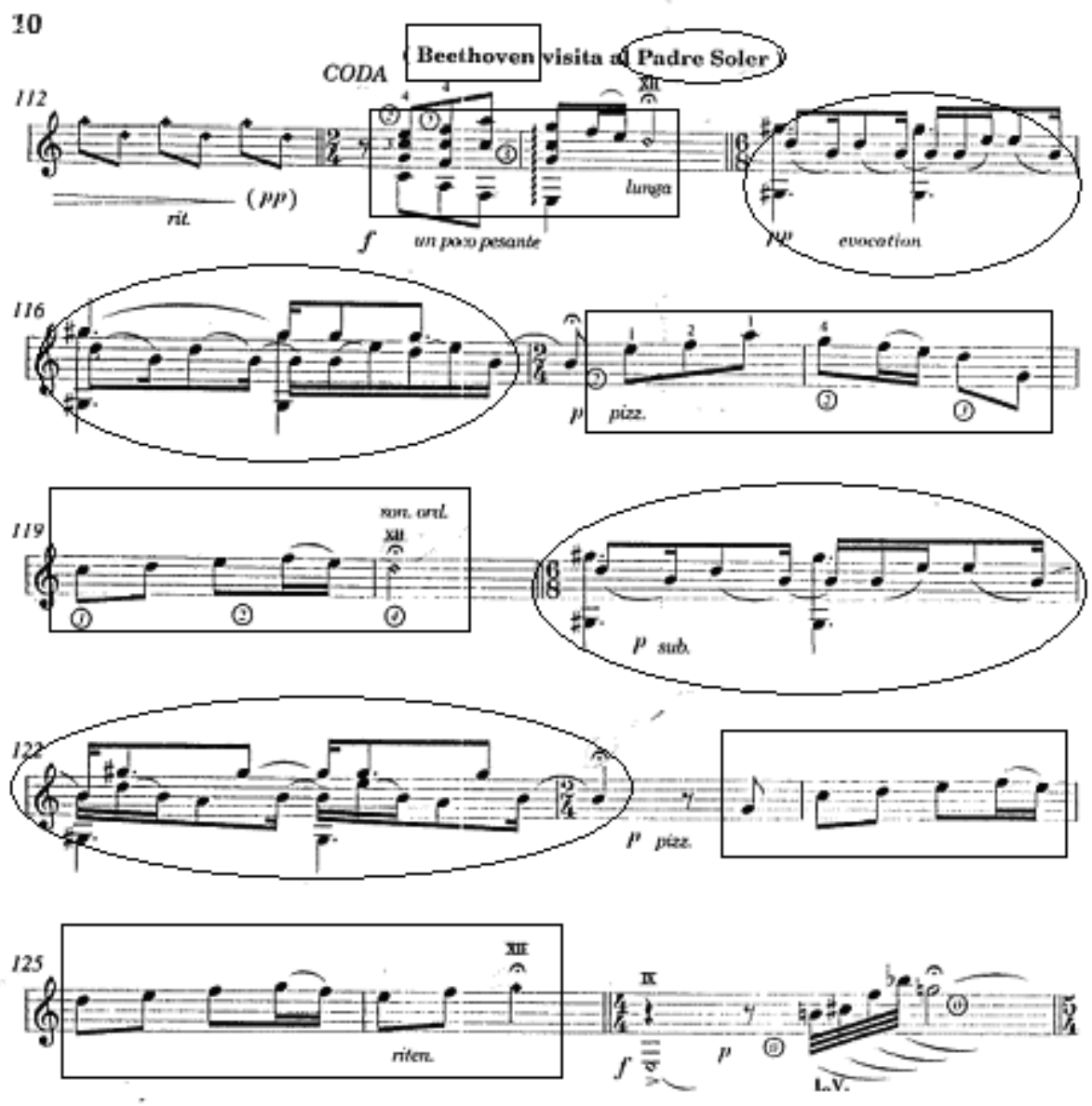

Fig.25: Fandangos y Boleros, "Coda", c. 112-127
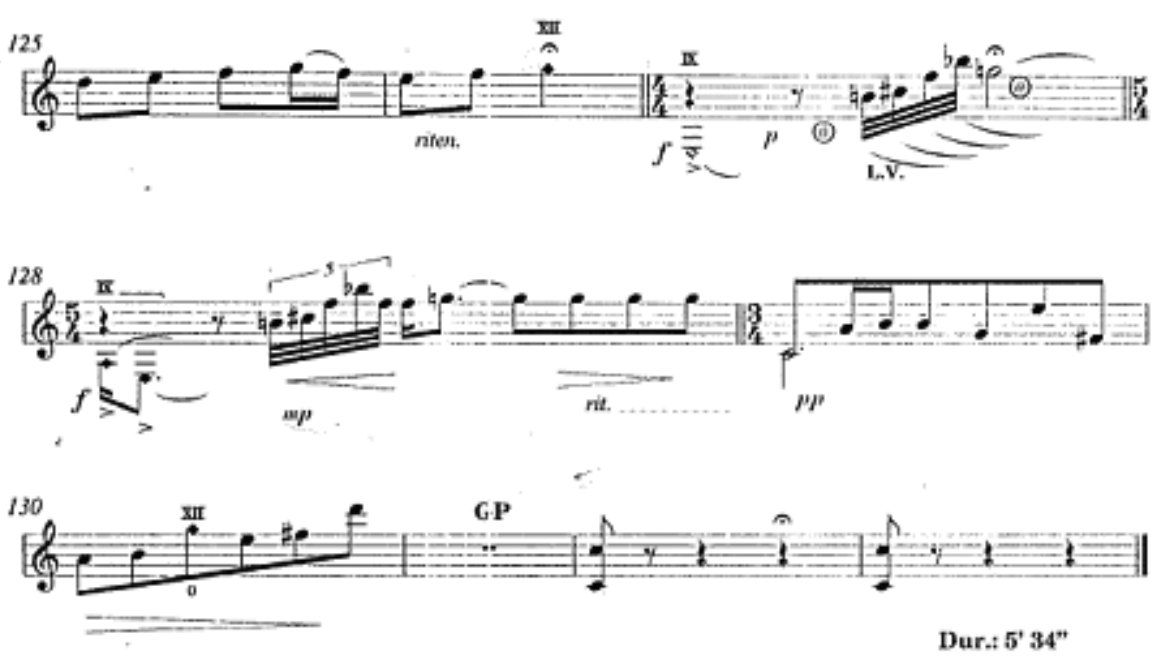

Fig.26: Fandangos y Boleros, "Coda", c. 125-133

Preámbulo $\longrightarrow$ Danza $\longrightarrow$ Alla Danza $\longleftarrow$ Alla Danza $\longleftarrow$ Coda

Fig.27 - Diagrama formal da Sonata 


\section{3- Ekphrasis}

Na presente análise, um primeiro aspecto a se considerar é que, diferentemente dos compositores analisados por Bruhn - que se baseavam, cada um deles, em uma obra determinada para suas composições -, Brouwer se baseia em um procedimento desdobrado por Paul Klee em toda a série de Quadrados Mágicos; ou seja, a organização de figuras coloridas com formas derivadas do quadrado em torno das três cores básicas - vermelho, amarelo e azul -, visando criar efeitos como movimento, ritmo e luminosidade. Portanto, utilizaremos diferentes quadros de Klee em nossa análise.

\section{1- Macro-forma}

Segundo DEVINE (2006), "Brouwer descreve o primeiro movimento [de sua Sonata] como um tipo de quebracabeça no qual as cores são recompostas e redistribuídas como nos Quadrados Mágicos de Paul Klee". Em relação à organização macro-formal, KAGAN (1993), referindose ao quadro Neue Harmonie (Fig.28), pintado por Klee em 1936 e pertencente à série de Quadrados Mágicos, demonstra que a composição é baseada no princípio de simetria bilateral invertida (o lado direito do quadro é um reflexo de cabeça-para-baixo do esquerdo).

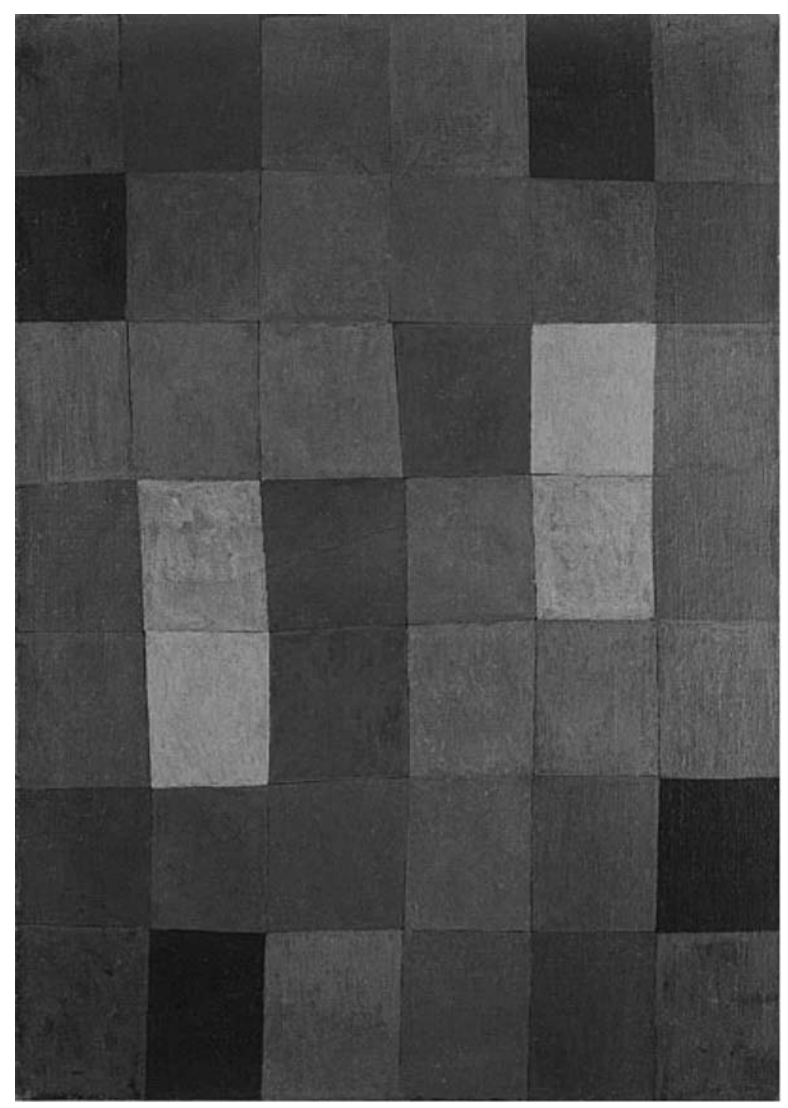

Fig.28: Paul Klee. Neue Harmonie. 1936. (86 x 60cm)

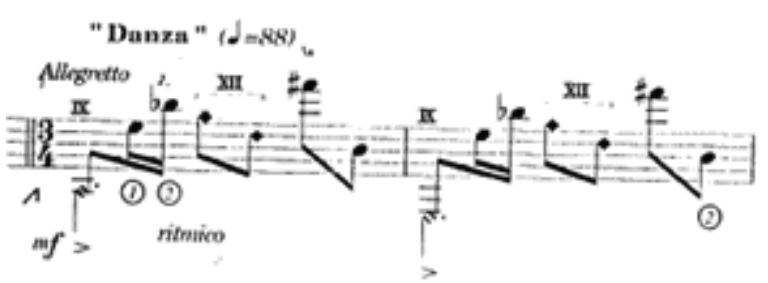

Fig.29a: Fandangos y Boleros, "Danza", c.13-14

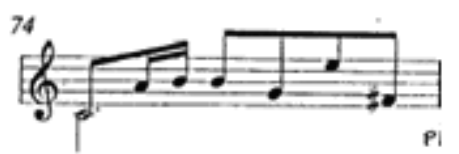

Fig.29b: Fandangos y Boleros, "Alla Danza", c.74 
Essa dialética entre as partes da mesma obra, que parece reproduzir-se a si mesma, se inicia, no caso de Brouwer, pelo título dado ao primeiro movimento; basta que consideremos a profunda associação entre os ritmos de fandango e de bolero, conforme assevera ROSAR (2001, p.542): "Sua métrica (a do fandango), associada com a do bolero e da seguidilla, era originalmente notada em 6/8, mas depois em 3/8 ou 3/4." A análise formal da peça de Brouwer, evidenciou ainda mais essa simetria, que pode ser compreendida através do diagrama da Figura 27.

É importante lembrar, conforme já dissemos, que os materiais da peça são apresentados em seu estado bruto no Preámbulo e começam a ser organizados na Danza, para serem desenvolvidos na Alla Danza (I), reorganizados na Alla Danza (II), e "explicados", novamente em estado bruto, na Coda.

Esse princípio de "espelhamento formal" pode ser verificado pela simples comparação de trechos da Danza e da Alla Danza (II), como mostrado nas Fig.29a e Fig.29b.

Nas seções externas - o Preámbulo e a Coda - tal espelhamento ocorre entre os arquétipos (ou statements) expostos no c. 1 e o tema de Beethoven, citado no c.113, ou seja, os principais elementos geradores da peça.

\section{2- Utilização de "cores" básicas} Sobre a criação dos Quadrados Mágicos, PIOCH (2002) nos diz que

"Os estudos realizados por Klee sobre história natural, anatomia comparada e antropologia geraram nele a crença de que a natureza era caracterizada pela permutação e movimento de unidades fundamentais de construção".

Em sua tentativa de trabalhar com essas unidades básicas,

"(...) Klee desenvolveu um sistema de organização no qual todas as cores do espectro eram concebidas como se movendo em torno de um eixo central dominado pelas três cores pigmentares - vermelho, amarelo e azul." (idem)

0 tratamento dado a ambos - os arquétipos (Fig.30a) e o tema de Beethoven (Fig.30b) supra-citados - nos remete a forma como os Quadrados Mágicos se desenvolvem em torno de cores básicas, que normalmente ocupam lugar central e têm função estrutural; como Klee faz com as cores, Brouwer combina, produzindo autênticas derivações, como a do c.13 (Fig.30c):

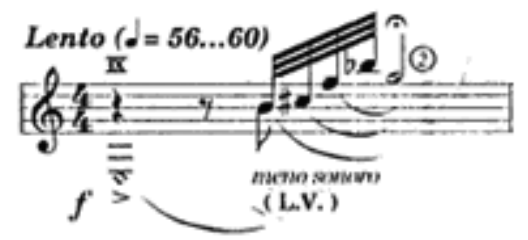

Fig.30a: Fandangos y Boleros, "Preámbulo" c.1

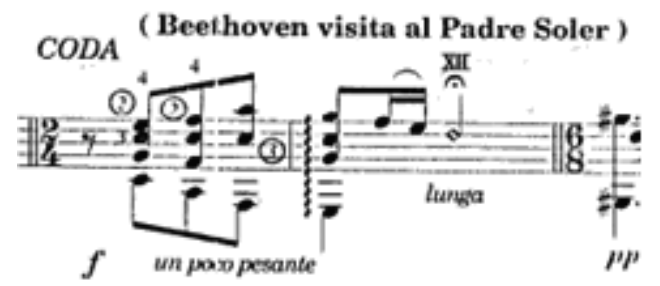

Fig.30b: Fandangos y Boleros, "Coda", c.113

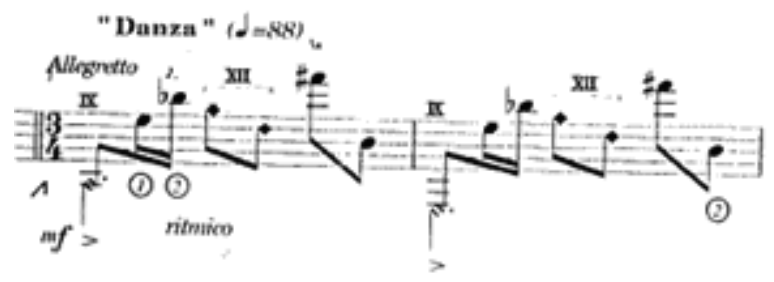

Fig.30c: Fandangos y Boleros, "Danza", c.13-14 
Nesse caso, o modelo apresentado no c.13 (Fig.30c) incorpora uma série de características intervalares do c.1 (Fig.30a) - o destacado intervalo de terça menor (Sib-Sol) descendente, antecedido por um intervalo mais amplo, e posicionado como arsis e tesis, bem como a colocação de uma nota grave no primeiro tempo - e a retrogradação ("espelhamento", novamente) rítmica do c.113 (Fig.30b).

Aqui importa lembrar a menção a um tema de Scriabin, a partir do c.7 (Fig.4 acima). Ocorre que este compositor se notabilizou, entre outras coisas, por seu profundo senso sinestésico ${ }^{16}$, que o levou a imaginar um teclado de luzes, onde cada nota corresponderia a uma cor (Fig.31).

Poderíamos, portanto, aplicar a idéia de colorido e luminosidade a cada nota, e imaginar que a polarização em determinadas notas ou regiões harmônicas corresponderia ao uso de cores matrizes e das suas combinações.

\section{3- Luminosidade}

A luminosidade conseguida por Klee pela aplicação e combinação de cores e tonalidades encontra também sua contrapartida musical. Uma atenta observação

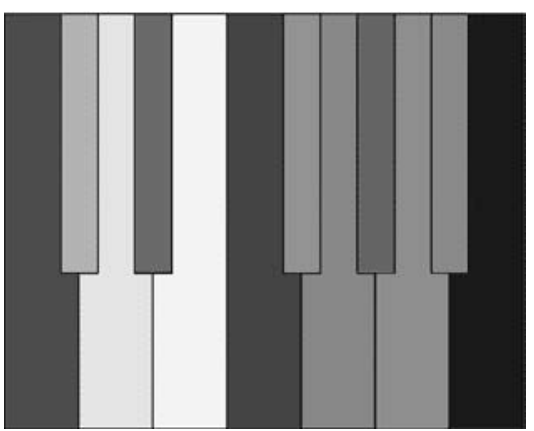

Fig.31: "Teclado de Scriabin"

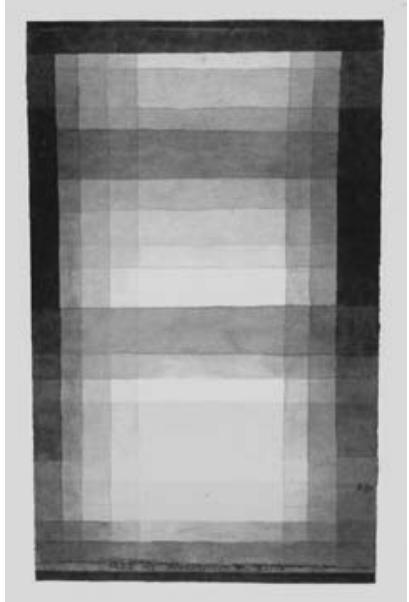

Fig.32a: Paul Klee. Architectur der Ebene. 1923. $(28,1$ x 17,7cm)

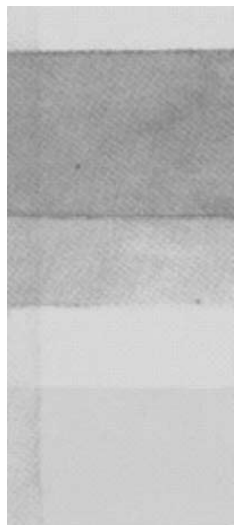

Fig.32b: Paul Klee. Fragmento onde fica clara a delimitação de cada cor 
demonstra que, embora nitidamente delimitadas (Fig.32b), as cores de determinados Quadrados Mágicos conseguem gerar a ilusão de emitirem luz, como no exemplo abaixo (Fig.32a):

0 resultado é que objetos apresentados individualmente são trabalhados de forma a se comportarem como se fossem uma coisa só. Tal efeito é alcançado em Fandangos y Boleros principalmente nos velozes gestos da Alla Danza, como o exemplificado na Fig.33b.

No c.1, o efeito de ressonância de cada nota tocada anteriormente cria uma "nuvem" em torno da nota Sol, preenchendo de harmônicos o espaço textural em torno da mesma (Fig.33a). Tal efeito é elaborado no c.44 (Fig. 33b), onde, ao invés da harmonia das ressonâncias e da textura, a passagem ultra-veloz por cada nota e sua existência efêmera produz um efeito violento e inesperado como um clarão de luz. Observe-se que a resultante harmônica dessa passagem é também derivada do c. 1, já que as notas utilizadas são as mesmas - Sib, Dó\#, Sol, Sib, agora acrescidas de Fá e Mi. Essa idéia será empregada sistematicamente, como se incorporasse uma reminiscência dos compassos iniciais da peça, ao longo da Alla Danza (I) (c.51, 68, 70, 71). 0 mesmo processo surge ainda nos c.17 a 23 (da Danza), e 87 a 89, 93 a 95, 102, 104 e 106 (da Alla Danza [II]).

\section{4- Citações}

Conforme PIOCH (2002) e DI SAN LAZZARO (1965, p.171174), os quadros de Klee realizavam uma sintese de seus estudos sobre música (mesmo porque esta ocupa lugar importante em sua inspiração e sua obra). Aliás, o próprio Klee apresenta exemplos de ekphrasis de obras musicais, como as pinturas Der bayrische Don Giovanni (1919), Fuge in rot (1921), Pastorale (Rhythmen) (1927), ou Im Bachschen Stil (1919).

É interessante frisar que, assim como Klee - que faz referência a música na pintura -, Brouwer, incorporando o procedimento composicional, também recorrerá a esse expediente. Podemos dizer que Klee e Brouwer falam de música, respectivamente, na pintura e na música.

0 uso de citações a outros músicos e músicas em Fandangos y Boleros - Scriabin, Soler, Beethoven - é recorrente, cíclico ${ }^{17}$ e estruturante. 0 próprio título do movimento - bem como os dos demais - demonstra parentesco com os que Klee dava às suas obras; como se Brouwer pretendesse "retratar" os caracteres desses ritmos e compositores.

\section{5- "Polifonia"}

Se considerarmos que Klee definia polifonia como "a simultaneidade de diversos temas independentes" (PIOCH, 2002), encontraremos na Sonata de Brouwer um exercício exato desse conceito, conforme se depreende da combinação de universos tão diversos quanto Beethoven, Scriabin, Soler, o próprio Klee, entre outros. Exemplo disso na obra do pintor encontramos em Ad Parnassum (1932) (Fig.40), quadro que concluiu a série de Quadrados Mágicos. Nele, Klee apresenta um modelo onde diversas de suas idéias e experiências pessoais são representadas, numa ilustração que retrata, conforme Pioch (idem), o portal do Monte Parnassum, a casa de Apolo e as Musas, as Pirâmides do Egito ${ }^{18} \mathrm{e}$, ainda, uma montanha perto da residência do pintor (Fig.34).

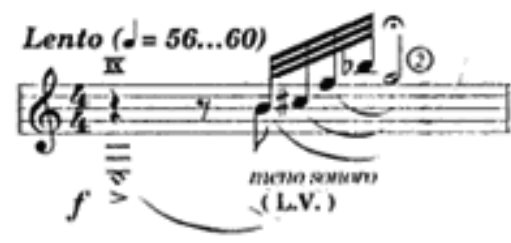

Fig.33a: Fandangos y Boleros, "Preámbulo", c.1

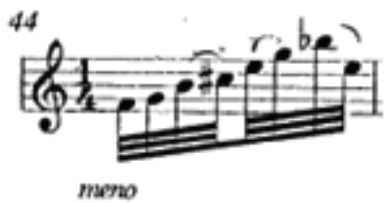

Fig. 33b: Fandangos y Boleros, "Alla Danza", c.44 


\section{4 - Conclusões}

Para entender uma composição tão abrangente, que abarca em si tantos e tão variados elementos, faz-se necessárias algumas considerações.

0 atual período da produção musical de Brouwer - que se inicia a partir de meados da década de 80 , e no qual se insere a Sonata - "(...) é chamado por ele mesmo de "Hiper-Romantismo Nacionalista", e caracteriza-se pelo "retorno às formas tradicionais, pelo uso de escalas pentatônicas, modalismo (...)" (DUDEQUE, 1994, p.98-99), dando preferência a uma linguagem difusa e de caráter hibrido, com freqüentes empréstimos do minimalismo, da música pop e da world music.

\section{Brouwer se explica (BETANCOURT, 2006):}

\begin{abstract}
"Com o tempo, eu percebi uma saturação da linguagem da chamada vanguarda. 0 que aconteceu é que este tipo de linguagem atomizada, seca e tensional sofreu, e ainda sofre, um defeito relacionado à essência do equilibrio composicional, um conceito que está presente na história: movimento, tensão e seu conseqüente repouso ou relaxamento. Esta "lei de forças opostas" - dia-noite, masculinofeminino, yin-yiang, tempo de amar, tempo de odiar - existe em todas as circunstâncias da humanidade. (...) A vanguarda sentia falta do relaxamento das tensões. Não há ente vivo que não descanse. Dessa maneira, eu fiz uma regressão na direção da simplificação dos materiais composicionais. Este é o que considero minha última fase, que chamo de "Nova simplicidade", e que abrange os elementos essenciais da música popular, da música clássica e da própria vanguarda. Elas me ajudam a dar contraste às grandes tensões".
\end{abstract}

Segundo ZANON (2000), "o enfoque está numa poética musical derivada de Barthes e İtalo Calvino, em que vários espaços-tempos coexistem na mesma composição". Sem sombra de dúvida, é o que podemos verificar após a análise da Sonata: a busca de outros níveis do que MOLINA (2003, p.121) chama de "virtuosismo composicional"19, se concentrando nas possibilidades de desenvolvimento de pequenas células-geratrizes e utilizando elementos de inspiração extramusical para criar suas obras. A criação de uma enorme teia de referenciais, iniciada na tentativa de apropriação de um procedimento da pintura, encontra aqui uma imaginativa forma de conciliar influências, tendências; universos, enfim, aparentemente tão distantes.

É como se, em uma época globalizada, marcada pelo "enfraquecimento das certezas etnocêntricas da cultura clássica" (ZANON, 2003, p.56), e em que a velocidade de produção e propagação da informação ultrapassa em muito nossa capacidade de absorção, Brouwer buscasse sintetizar elementos remotamente conciliáveis, nos quais ele demonstra haverem pontos de contato, criando um efeito quase fantasmagórico, em que múltiplas culturas passam rápida e quase imperceptivelmente diante de nossos ouvidos. (É no mínimo curioso verificar, por exemplo, que existe uma possível relação entre o tema da $6^{a}$ sinfonia e o bolero...) Sustentando o argumento musical num edifício criativo baseado em outras mentes que, cada uma a seu modo, buscaram sínteses (Klee, Scriabin, Beethoven), Brouwer evoca o historicismo que marca a sociedade atual, convivendo e cultivando a cultura do passado, ao mesmo tempo em que busca se lançar em direção a um futuro; sem negar as influências, e se reservando a um resultado original.

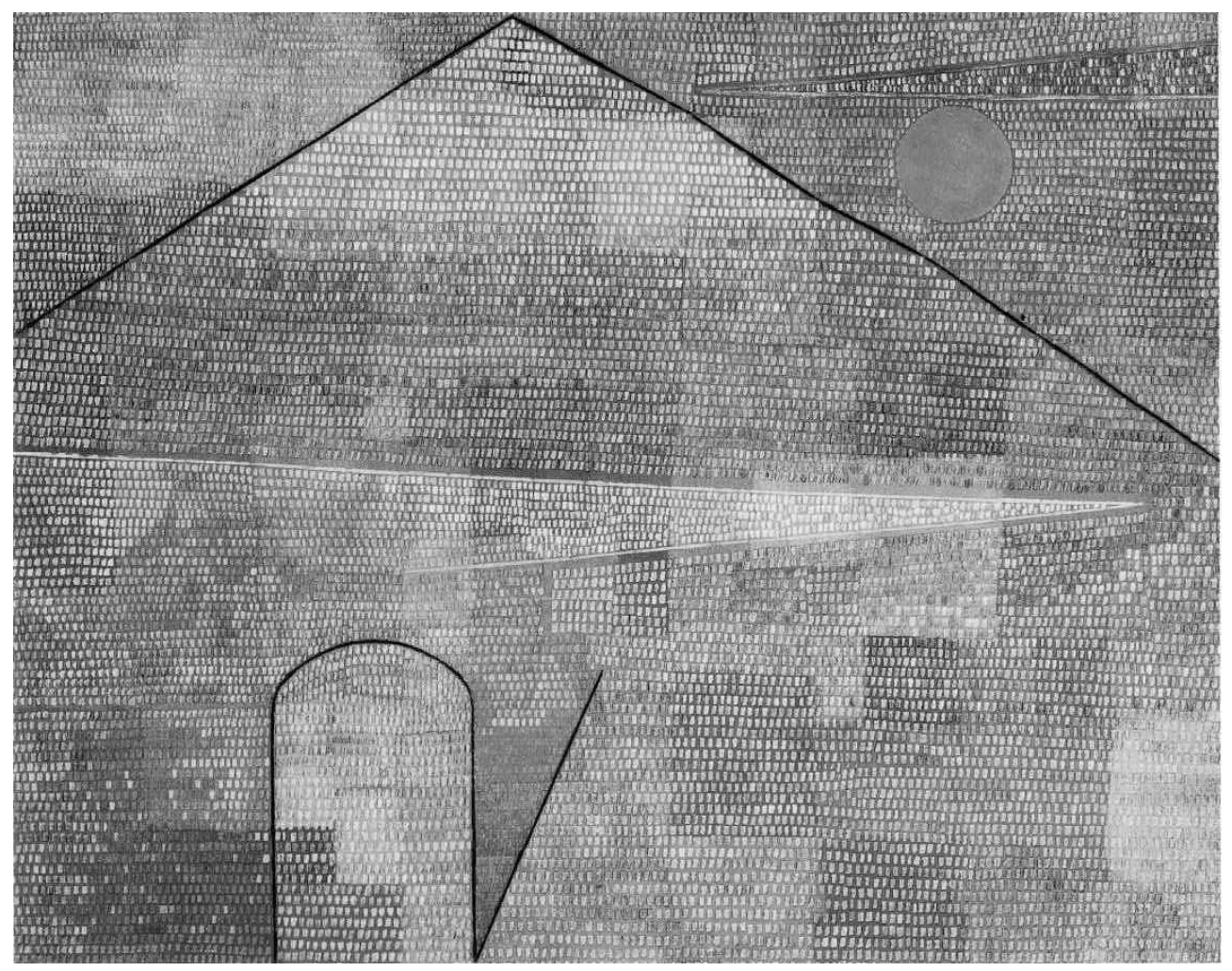

Fig.34: Paul Klee. Ad Parnassum, 1932. (100 x 126 cm.) 


\section{Referências}

BEETHOVEN, Ludwig van. Symphony no. 6 (Pastorale). [música]. New York: Edition Eulenburg Inc. [s. d.]

BETANCOURT, Rodolfo. A Close Encounter with Leo Brouwer. [Entrevista on-line, 2006]. Disponivel em: <http://www. musicweb.uk.net/brouwer/rodolfo.htm>. Acesso em 8 de maio de 2006.

BRUHN, Siglind. Musical Ekphrasis: Composers Responding to Poetry and Painting. Hillsdale: Pendragon Press, 2000.

BROUWER, Leo. Sonata. [música]. Madrid: Opera Tres, Ediciones Musicales S. L., 1991.

DEVINE, Graham Anthony. Leo Brouwer. [texto on-line, 2006]. Disponivel em <http://www.naxos.com/mainsite/NaxosCat/ Naxos_Cat.asp?item_code $=8.554195 \#>$. Acesso em 10 de maio de 2006.

DI SAN LAZZARO, G. Klee: His Life and Work. Londres: Thames and Hudson, 1965. 304 p.

DÜCHTING, Hajo. Paul Klee: Painting Music. Munique: Prestel-Verlag, 1997. 112 p.

DUDEQUE, Norton Eloy. História do Violão. Curitiba: Editora da UFPR, 1994. p. 98 - 99

GARCIA, E.E. Rachmaninoff and Scriabin: Creativity and Suffering in Talent and Genius. Psychoanalytic Review, 91:423442, 2004.

KAGAN. Andrew. Paul Klee At The Guggenheim Museum. New York: Guggenheim Museum, 1993. 203 pp.

MARVIN, Frederick. Soler (Ramos), Antonio (Francisco Javier Jose). In: SADIE, Stanley. The New Grove Dictionary of Music and Musicians. Londres: Macmillan Publishers Limited, 2001, vol. 23. p. 633 - 634.

MOLINA, Sidney. Construção da mentira em Paisaje Cubano con Lluvia de Leo Brouwer: uma análise semiótica. GALÁXIA Revista Transdisciplinar de Comunicação, Semiótica, Cultura. São Paulo, EDUC / CNPQ, vol. 6, pp. 121-144, out. 2003.

MORRISON, Bryce. Bolero. In: SADIE, Stanley. The New Grove Dictionaty of Music and Musicians. Londres: Macmillan Publishers Limited, 2001, vol. 3. p. 819 - 822.

PIOCH, Nicolas. Ad Parnassum. [artigo on-line, agosto de 2002]. Disponivel em: <http://www.ibiblio.net/wm/paint/auth/ klee/>. Acesso em 5 de junho de 2006.

ROSAR, William H. Fandango. In: SADIE, Stanley. The New Grove Dictionaty of Music and Musicians. Londres: Macmillan Publishers Limited, 2001, vol. 8. p. 542 - 543.

SCRIABIN, Alexandre. Sonata no I, Op. 6 [música]. Per Hartmann Editions. [S. L.: S. P.]

SCRIABIN, Alexandre. Sonata no III, Op. 23 [música]. Per Harmann Editions. [S. L.: S. P.]

WADE, Graham. Leo Brouwer. In: SADIE, Stanley. The New Grove Dictionaty of Music and Musicians. Londres: Macmillan Publishers Limited, 2001, vol. 4. p. 437 - 438.

ZANON, Fábio. A Arte do Violão. [série de programas de rádio apresentados na Rádio Cultura FM de São Paulo a partir de setembro de 2003]. Disponivel em: <http://paginas.terra.com.br/arte/violao_intercambio/Ultimaedicao/ArtedoViolao/ Artedoviolao.htm>. Acesso em 10 de dezembro de 2005.

ZANON, Fabio. Leo Brouwer [artigo on-line]. Disponivel em: < http://www.violao.hpg.ig.com.br/brouwer.html>. Acesso em 28 de novembro de 2006.

Ricardo Marçal tornou-se bacharel em música pela UFMG em 2007; habilitou-se em violão, na classe do professor Fernando Araújo. Tem atuado intensamente como solista - interpretando principalmente obras do século XX e XXI, inclusive estreando novas composições - e com conjuntos de câmara, participando de concertos nas mais importantes salas de Minas Gerais e em diversas cidades brasileiras e realizando gravações. Na área de pesquisa em música, recebeu orientação do professor André Cavazotti.

\section{Notas}

1 Paul Klee era violinista, foi integrante da Bern Municipal Orchestra durante algumas temporadas e era musicólogo amador: "Os registros no diário de Klee e suas correspondências estão repletos de penetrantes discussões sobre questões musicais assim como análises criticas de obras musicais e suas performances. Durante a temporada de 1911-12, ele era o crítico correspondente do periódico de Bern, Die Alpen, comentando sobre arte, concertos, ópera e teatro em Munich" (BRUHN, 2000, p.362). Obs.: todas as traduções foram feitas pelo autor do presente trabalho, exceto quando indicado.

2 "Não deve haver um pintor ou desenhista no século XX que lidou tão intensivamente com a música como Paul Klee, fazendo-Ihe referência explícita tanto em sua arte como em seus escritos." (DÜCHTING, 1997, p.7)

3 Percepção na qual dois sentidos estão combinados. Do grego syn (união) e aesthesis (sensação).

4 Série de quadros executada entre 1923 e 1932 em que ele utiliza, como procedimento composicional, a organização de figuras coloridas com formas derivadas do quadrado em torno das três cores básicas (vermelho, amarelo e azul), visando criar efeitos como movimento, ritmo e luminosidade.

5 Segundo o violonista inglês Graham Anthony Devine, autor dessa referência - e que nos atendeu gentil e prontamente via correio eletrônico - essa informação veio do próprio Leo Brouwer.

60 violonista escocês Paul Galbraith, em aula ministrada no dia 22/06/2006, nos sugeriu o vocábulo inglês statement para descrever esse motivoarquétipo.

7 A notação de harmônicos no violão, bem como em outros instrumentos, carece de padronização. No texto musical analisado, o compositor optou por escrever a cabeça da nota correspondente à corda que será tocada com o formato de um losango ou "diamante", indicando acima dela o número da casa em que o harmônico será produzido 
80 segundo movimento da Sonata em estudo é apropriadamente intitulado Sarabanda de Scriabin.

9 Tocada novamente como harmônico, e utilizando a notação anteriormente explicada.

10 "Variáveis interpretações dessa dança são encontradas no México, Cuba e outras nações latino-americanas, especialmente Colômbia e Venezuela." (MORRISON, 2001, p.820)

11 A respeito do gênero Fandango, assim se expressa Rosar (2001, p.542): "Sua métrica, associada com a do bolero e da seguidilla, era originalmente notada em 6/8, mas depois em 3/8 ou 3/4."

12 Compositor e organista catalão. "Um sabor espanhol é evidente em suas obras no uso de ritmos de dança e cores cintilantes. Um notável exemplo é seu Fandango, uma longa peça de 462 compassos, construída em um ostinato entre Lá maior e Ré menor que evolui de uma calma introdução, através de dissonâncias, síncopes e vistosas variações, para um tempestuoso clímax" (MARVIN, 2001, p.633). Tal como Fernando Sor (1778-1839), um dos mais importantes compositores da primeira "Época de Ouro" do violão (ZANON, 2003, p.5), foi aluno no mosteiro de Montserrat.

130 manuscrito do texto musical - cuja cópia nos foi gentilmente cedida pelo violonista chileno José Antonio Escobar -, bem como a edição, destacam 0 início de cada repetição com uma letra, de $A$ até $F$.

14 Utilizando a notação de harmônicos anteriormente descrita.

15 Mesmo número de repetições do padrão dominante/mediante da seção anterior.

16 "Em suas autobiográficas Recordações, Sergei Rachmaninoff registrou uma conversação com Scriabin e Nikolai Rimsky-Korsakov sobre a associação feita por Scriabin entre cor e música. Rachmaninoff estava surpreso por ver que Rimsky-Korsakov concordava com as associações de Scriabin entre tonalidades musicais e cores; ele mesmo um céptico, Rachmaninoff fez a objeção óbvia de que os dois compositores nem sempre concordavam sobre as cores envolvidas. Os dois sustentavam que a tonalidade de Ré maior era marrom-dourado; mas Scriabin ligava Mi bemol maior com vermelhopúrpura, enquanto Rimsky-Korsakov preferia azul. De qualquer forma, Rimsky-Korsakov alegou que uma passagem da ópera 0 Cavaleiro Avarento de Rachmaninoff sustentava seus pontos de vista: a cena na qual o Velho Barão abre as arcas de tesouros para revelar o ouro e as pedras preciosas cintilando sob a luz das tochas foi escrita em Ré maior. Scriabin disse a Rachmaninoff: 'sua intuição inconscientemente seguiu as leis cuja existência você tem tentado negar'". (GARCIA, 2004)

17 Não apenas o procedimento será de fundamental importância nos próximos movimentos (Sarabanda de Scriabin e La Toccata de Pasquini), mas também as próprias citações do primeiro. Nestes, o tema de Scriabin ocupa especial relevância.

18 Que Klee contemplou em visita ao Egito, em 1928.

19 "...o virtuosismo composicional de Brouwer na estrutura profunda, gramática narrativa e estrutura discursiva pode ser oculto sob uma aparente simplicidade na manifestação." (MOLINA, 2003, p.121) 